\title{
Selection of Lactic Acid Bacteria (LAB) Origin of Food Fermentation Probiotic Mixed as Candidate
}

\section{for Broiler}

\author{
Aprisal $^{1}$, Yetti Marlida ${ }^{2 *}$, Husmaini $^{2}$, Harnentis ${ }^{2}$
}

\author{
${ }^{1}$ Magister Student at Graduate Program of Faculty of Animals Science at Universitas Andalas, Kampus Limau Manis, Padang, Indonesia, \\ 25163 \\ ${ }^{2}$ Lecturer at Under Graduate of Faculty of Animal Science, Universitas Andalas, and Graduate Program at Universitas Andalas, Kampus Limau \\ Manis, Padang, Indonesia, 25163 \\ 2*Corespondens Author :yettimarlida@yahoo.com / yettimarlida@ansci.unand.ac.id
}

\begin{abstract}
This research aims to looking for 2 candidates from the new probioticlactic acid bacteria fermented food origin. This study uses seven isolates were isolated from whey, cassava, and fish budu. 7 isolates have been tested potential as a producer of glutamic acid but not known as a candidate probiotic petensinya. This study uses a completely randomized design, each repeated 3 times with 5 stages of the research are: 1) Testing capability isolates at low pH (pH 2.5); 2) testing the ability of isolates in bile (0.3 and 0.5\%); 3) Viability isolates 4) Testing capability isolates in killing the pathogenic bacteria (Escherichia coli, Staphylococcus aureus and Salmonella enteritidis). The results showed the 7 isolates can be used as a probiotic candidates with the results of the resistance to $\mathrm{pH} 2.5$ for 3 hours is $63.91-92.75 \%$ and the 6 hour incubation is 48,76-72.44\%, resistance to bile salt concentration of 0.3\% showed resistance to $22.86-83.57 \%$ and a concentration of $0.5 \%$ showed resistance $18.35-72,77 \%, 81.05-92.67 \%$ viability and inhibitory effect on the bacteria Escherichia coli is 7:33 to 12:01 mm, is 11:11 to 14:05 mm Staphylococcus aureus and Salmonella enteritidis is 12:02 to 18:08 mm. From 7 isolates after penseleksian ability as a candidate probiotic mixture then isolate F6 from durian fermented and isolate C8 from buffalo milk fermented (Dadih) are able to live at pH 2.5 for 3 hours of $92.75 \%$ and $86.06 \%$, at 6 hours of 72.44 and $71.42 \%$, the bile salt $0.3 \%$ were $83.57 \%$ and $78.75 \%$ and the concentration $0.5 \%$ are $77.17 \%$ and $72.77 \%$, with viability were $92.67 \%$ and $92.23 \%$, while the ability to kill pathogens such as Escherichia coli was 10.49 and $8.89 \mathrm{~mm}$, Staphylococcus aureus was 14.05 and $13.70 \mathrm{~mm}$, dan Salmonella enteritidis was 18.08 and 14.18 mm.
\end{abstract}

Keywords - Lactic Acid Bacteria, Pathogenic Bacteria, Bile Salts, pH 2.5, Probiotics.

\section{INTRODUCTION}

Antibiotic growth promoter is that antibiotics are often mixed in animal feed or drinking water. The use of antibiotic feed additives aimed at spurring growth, improving productivity, disease prevention, and feed efficiency. Usage of antibiotics to livestock has been ongoing since 1940 (Castañon 2007). The use of antibiotics in a sustainable and continuous endanger human health cause resistance among bacterial pathogens to antibiotics (Vignaroli et al., 2011) and the accumulation of residues of antibiotics in livestock meat (Tao et al., 2012). In Indonesia, the Ministry of Agriculture has issued Law No. Animal Husbandry and Animal Health 18 Year 2009 Article 22, Paragraph 4c which prohibits the use of antibiotics as feed additives (Ministry of Agriculture,
2009). The threat of a bad influence of antibiotics is also a serious concern to the researchers to conduct a search of alternative materials feed additives. One alternative feed additives that can be used are probiotic.

Probiotics are live microorganisms which when consumed can improve the health of livestock in a way to balance the microflora in the digestive tract when consumed in sufficient quantities. Probiotic bacteria are non-pathogenic microorganisms which, when consumed a positive influence on physiology and health of its host (Schrezenmeir and de Vrese, 2001). One type of bacteria that is often used as probiotics for livestock ungags are lactic acid bacteria (LAB). BAL is one of a group of bacteria that acts as a probiotic where these bacteria live in the digestive tract of 
cattle. The use of lactic acid bacteria (LAB) as probiotic microorganisms has been ongoing since 1965 (Fuller, 1992).

Lactic acid bacteria (LAB) are a group of Gram positive cocci or rod-shaped, spore-forming, the optimum temperature $\pm 40^{\circ} \mathrm{C}$, is generally not motile, anaerobic, catalase negative and positive oxidase, with lactic acid as the main product of carbohydrate fermentation.Lactic acid bacteria (LAB), which formed large potential used as a probiotic for lactic acid bacteria include microorganisms safe when added to food because it is not toxic and does not produce toxins, so-called food-grade microorganism known as microorganisms Generally Recognized As Safe (GRAS ) is a microorganism which no risk to human health, even some types of bacteria are useful for human health (Kusmiati and Malik, 2002). In addition BAL also produces several compounds that function as antimicrobial mainly organic acids, hydrogen peroxide, and the fractions of proteins called bacteriocins (Ouwehand and Vesterland, 2004).

Lactic Acid Bacteria (LAB) has long been known for its role in the fermentation process that produces food products with different characteristics and flavor than fresh food. Some food fermentation produces lactic acid bacteria which are curd,cassava, and fish budu. Of the fermented food has been in isolation as much as 7 species of lactic acid bacteria. Seventh isolates have been tested using $\mathrm{CaCO} 3$ to determine that the ten isolates the lactic acid bacteria. The results of the test showed the ten isolates $\mathrm{CaCO} 3$ formed a clear zone disekitarannya, this means tersbut isolates classified as lactic acid bacteria (Maslami, 2019). Maslami (2019) have also proved that the seven isolates is glutamic acid-producing but not yet proven as a candidate probiotic.

FAO / WHO (2002) has set the minimum criteria that must be owned by probiotics as feed additives, namely 1) strain of probiotics should be identified characteristic phenotype or genotype, 2) In vitro assays, strains of probiotics should be able to live in the gastric acid and bile salts, able to stick to the mucus or intestinal epithelial cells, capable of producing antimicrobial that can suppress the growth of pathogenic bacteria, 3). Probiotic strains do not produce toxins, do not have properties resistant to antibiotics, and are not pathogenic.

The bacteria used as probiotics are still mostly given in the form of single or one type of strain. Still not much to look at giving some types of bacteria as probiotic mixture. The use of probiotic mixture to provide benefits more effective than the administration of one type of strain. This is in accordance with the opinion of Sanders and Veld (1999) which states that the use of multi-strain probiotics are more effective than single probitik, and more resistant to microbial infection.Effect of probiotic multistrain more effective as a spur growth of broiler (Timmerman et al., 2006).This was reinforced by previous researchers provide evidence that probiotics multistrain more effective than single strains of probiotics (Timmerman et al., 2004).Based on the above, then do research selection and characterization of fermented food BAL origin to get 2 isolates of $\mathrm{LAB}$ as a candidate probiotic mix for broilers.

\subsection{Material Research}

\section{MATERIALS AND METHODS}

Materials used in this study is 7 isolates of lactic acid bacteria (LAB) from fermented food. The ten isolates (B2, C8, C36, F6, I22, L15 and P1) has been electrically insulated and has been tested $\mathrm{CaCO} 3$ earlier, MRS Broth, $\mathrm{HCl} 37 \%$, bile salts synthetic (oxgall), Nutrient Agar (NA), Escherichia coli , Staphylococcus aureus, Salmonella enteritidis, and others.

The tools used are bottle vial, a petri dish, vortex, test tubes, test tube rack, flask, beakers, micro pipette tip, hockey stick, Autoclaves, magnetic stirrer, hot-plate, Bunsen, laminar air flow, aluminum foil, Spectrophotometer, glass beaker, incubators, microscopes, $\mathrm{pH}$ meters, paper disk. Glass objects, needles ose, and others.

\subsection{Research Implementation}

This study was performed by using Experimental in Completely Randomized Designwith 7th isolates as treatment and each repeated 3 times.

\subsubsection{Revitalization of Lactic Acid Bacteria}

This research using 7 isolates were rejuvenated beforehand that aims to reactivate the stored isolates dilemari Cooling. Making the media for the rejuvenation of 7 isolates of lactic acid bacteria is by as much as 7.8 grams of MRS broth dissolved in $150 \mathrm{ml}$ of distilled water. Then heated over a hot plate while stirring until homogenous. MRSB $10 \mathrm{ml}$ of media was added to each vial bottle and then sterilized in the autoclave at a temperature of $121 \mathrm{oC}$ for 15 minutes. $1 \mathrm{ml}$ lactic acid bacteria isolates taken using a micropipette and put into $10 \mathrm{ml}$ MRS broth and incubated for 24 hours at a temperature of $37^{\circ} \mathrm{C}$.

\subsection{Observed variables}

2.3.1. Selection of Lactic Acid Bacteria as a Probiotic Fermented Food Origin

Isolate Testing LAB (Lactic Acid Bacteria) made usingMRSB media (Man Ragosa Sharpe Broth) on various probiotic test ( $\mathrm{pH}$, bile salts and stickiness test). There are 7 
isolates (B2, C8, C36, F6, I22, L15 and P1) were tested in various test Probiotics.

\subsubsection{Gastric $\mathrm{pH}$ Resistance Test}

The test method of resistance to gastric $\mathrm{pH}$ is based on the modified method of Hardiningsih et al. (2006). The test is performed using 10 isolates of lactic acid bacteria. The test is performed by using a medium MRS Broth $37 \% \mathrm{HCl}$ is added to obtain a $\mathrm{pH}$ of 2.5 and a medium MRS Broth without the addition of $\mathrm{HCl}$ as a control with a $\mathrm{pH}$ of 6.8. Seterilisasi medium in the autoclave at a temperature of $121^{\circ} \mathrm{C}$ for 15 minutes. Bacterial isolates of $0.5 \mathrm{ml}$ put in MRS Broth- $\mathrm{HCl} 5$ $\mathrm{ml}$ and incubated for 3 and 6 hours at $37^{\circ} \mathrm{C}$. Then read the absorbance at a wavelength of $600 \mathrm{~nm}$. This study was conducted with three replications. Resilience isolates expressed as a percentage according Tokatli et al. (2015)

2.3.1.2. Bile Salt Resistance Test

The test method of resistance to bile salts was tested by the modified method of Vinderola and Reinheimer (2003). The test is performed using 10 isolates of lactic acid bacteria. Testing is done by adding a bile salt concentrations of $0 \%$, $0.3 \%$, and $0.5 \%$ in MRS broth medium. Medium sterilized by autoclave at a temperature of $121 \mathrm{oC}$ for 15 minutes. Bacterial isolates of $0.5 \mathrm{ml}$ put in a $5 \mathrm{ml}$ MRS broth that has been coupled with oxgall $0 \%, 0.3 \%$, and $0.5 \%$ and incubated at $37^{\circ} \mathrm{C}$ for 5 hours. Controls containing MRS broth without addition of bile salt concentration (concentration 0\%) compared with the treatment. Growth was measured by looking at the absorbance, at a wavelength of $600 \mathrm{~nm}$. This study was conducted with three replications. Resilience isolates expressed as a percentage according Tokatli et al (2015).

2.3.1.3. Power Test Inhibitory Bacteria Against Pathogens

Test the antimicrobial activity of 10 isolates of lactic acid bacteria against pathogenic bacteria (Escherichia coli, Staphylococcus aureus and Salmonella enteritidis) is based on a modification of the method Awalia (2017), with the working procedures as follows:

1. To be prepared Nutrient media as much as 10 grams in $500 \mathrm{ml}$ of distilled water, then homogenized and heated in a water bath, then in the autoclave.

2. After the media rather cold $\left( \pm 45^{\circ} \mathrm{C}\right)$ added $0.2 \%$ of the bacteria that have been in the enrichment test 24 hours beforehand, homogenized, and then poured into a petri dish as much as $\pm 10 \mathrm{ml}$, cooled to solidify.

3. Meanwhile soak the paper disk in lactic acid bacteria for about 10 minutes.
4. After that solidifies paper disk placed on the surface of the medium NA which already contain pathogenic bacteria.

5. After that, incubated for $24 \mathrm{~h}$ at $37^{\circ} \mathrm{C}$ aerobically.

6. After 24 hours measured the diameter of inhibition zone is formed using a caliper.

According to Toy et al. (2015)

\subsubsection{PowerTest Sticky or hydrophobicity}

Hydrophobicity or attachment test was conducted using DarriDewanti and Wong (1995), using a stainless steel plate. Stainless steel is cleaned of dirt on its surface by soaking with a hot detergent solution (40-45OC) for 24 hours. Then the plates were rinsed with hot water (40-45OC) to not frothy and smooth, then dried. Once dry, the one marked stainless steel.

A total of $5.22 \mathrm{~g}$ MRS Broth was dissolved into $100 \mathrm{ml}$ of distilled water as a medium for growth. Growth media and stainless steel autoclave at a temperature of $1210 \mathrm{C}$ for 15 minutes. Later stainless steel plate put in $25 \mathrm{ml}$ MRS Brothyang isolates were inoculated with $1 \mathrm{ml}$ of bacteria into erlemeyer, incubated for 24 hours at $37^{\circ} \mathrm{C}$. Furthermore, by using a stainless steel surface swab wiped evenly. Swab inserted into tubes containing $10 \mathrm{ml}$ phosphate buffer and homogenized. Then measured by the absorbance at a wavelength of $600 \mathrm{~nm}$ (A).

Measurement of growth in the liquid phase, in take $1 \mathrm{ml}$ of media and diluted into $9 \mathrm{ml}$ phosphate buffer solution. Then measured by the absorbance at a wavelength of $600 \mathrm{~nm}$ (Ao). The percentage of attachment can be calculated using the formula:

The diameter of inhibition zone $=($ Ao-A $) \times 100 \%$

(Ao)

\section{RESULTS AND DISCUSSION}

\subsection{Lactic Acid Bacteria Isolates resilience against Gastric pH}

Based on probiotic on acid resistance test $(\mathrm{pH})$ was performed using MRSB medium $0.1 \mathrm{~N} \mathrm{HCl}$ is added to obtain a $\mathrm{pH}$ of 2.5 because the proventriculus and gizzard $\mathrm{pH}$ is 2.5 3.5(Surono, 2004). Results of lactic acid bacteria resistance to gastric $\mathrm{pH}$ can be seen in Table 1 . 
Table 1. The mean Resilience (\%) of lactic acid bacteria to pH 2.5

\begin{tabular}{ccc}
\hline \multirow{2}{*}{ Isolates } & \multicolumn{2}{c}{ Incubation time } \\
\cline { 2 - 3 } & $\mathbf{3}$ hours & $\mathbf{6}$ hours \\
\hline F6 & $92,75 \mathrm{a}$ & $72,44 \mathrm{a}$ \\
C8 & $86,06 \mathrm{~b}$ & $71,42 \mathrm{a}$ \\
C36 & $73,52 \mathrm{~cd}$ & $48,94 \mathrm{bc}$ \\
B2 & $69,37 \mathrm{de}$ & $52,90 \mathrm{~b}$ \\
L15 & $67,49 \mathrm{ef}$ & $50,98 \mathrm{~b}$ \\
I21 & $75,66 \mathrm{c}$ & $45,78 \mathrm{c}$ \\
P1 & $63,91 \mathrm{f}$ & $48,76 \mathrm{bc}$ \\
\hline SE & $\mathbf{1 . 6 2 5}$ & $\mathbf{1 . 3 0 7}$ \\
\hline
\end{tabular}

Note: superscript $=$ different letters in the same column showhighly significant $(\mathrm{P}<0.01)$

$\mathrm{SE}=$ Standard errer

Results of analysis of variance showed that each isolate $\mathrm{LAB}$ have different survival were significantly $(\mathrm{P}<0.01)$ on the condition of $\mathrm{pH}$ at 3 and 6 hours. F6 isolates have better survival against the acidic conditions at the time ingkubasi 3 hours and followed by $\mathrm{C} 8$ isolates with resistance level of $86.06 \%$. The lowest resistance to acid conditions with a time of incubation for 3 hours ie P1 isolates (63.91\%). Each LAB isolates decreased resistance at the time inkunasi 6 hours. Isolates F6 and $\mathrm{C} 8$ has the highest survival in acidic with 6hour incubation period compared isolate C36, B2, L15, I21 and P1. Isolates with low resistance is I21 (45.78\%). Table 1. Shows that viabililitas bacteria are incubated for 3 hours are from 63.91 to $92.75 \%$. The results of this study are higher than research Badarinath et al. (2009) isolated from the okara has survival at $\mathrm{pH} 2.5$ for 2 hours at $74.02 \%$. While research Tokatli et al. (2015) lactic acid bacteria strain of Lactobacillus plantarum, Lactobacillus brevis and Pediococcus ethanolidurans isolated from traditional pickles own survival at $\mathrm{pH} 2.5$ for 4 hours is $35-85 \%, 33-64 \%$ and $40-76 \%$.

The results of the study Table 1 shows all the lactic acid bacteria can survive at $\mathrm{pH} 2.5$ with a time of incubation for 3 hours and 6 hours, with minimal resistance $\geq 50 \%$, which means that all isolates of lactic acid bacteria can be used as probiotics. As presented bySieladie et al. (2011)that the lactic acid bacteria as probiotics criteria can survive at low $\mathrm{pH} \geq$ $50 \%$. BAL able to survive at low $\mathrm{pH}$ conditions caused $\mathrm{BAL}$ has some physiological factors capable of regulating cell intracellular $\mathrm{pH}$ homeostasis(Van de Guchte et al. 2002; Cotter and Hill 2003).Fardiaz, (1989) describes that the Gram positive bacteria have a cell wall composed of $90 \%$ peptidoglycan and other thin layer is teikoat acid. Thick peptidoglycan and this teikoat acid chains that can maintain the shape of the cell wall of acidic extracellular conditions. BAL cell wall can retain its shape, so that the inside of the cell can still be protected.

Upon entering the digestive tract with a very acidic $\mathrm{pH}$ conditions, the bacteria can experience stress. Stress experienced is due to different intracellular $\mathrm{pH}$ with $\mathrm{pH}$ extracellular bacteria, so the lactic acid bacteria have to do in order to adapt the metabolism of intracellular to extracellular conditions.Siegumfeldt et al. (2000)explained that the lactic acid bacteria are able to maintain intracellular $\mathrm{pH}$ more alkaline than a $\mathrm{pH}$ of extracellular, but a decrease in intracellular $\mathrm{pH}$ persist with decreasing extracellular $\mathrm{pH}$ which supports tolerance to acid. Bacteria can degrade intracellular $\mathrm{pH}$ around neutral when the extracellular $\mathrm{pH}$ drops, but will use a lot of energy because of the difference of the proton gradient and result in the accumulation of organic acids anions that are toxic to the cell cytosol(Russell, 1992). Furthermore, also described by Siegumfeldt et al. (2000), lactic acid bacteria dynamic changes of intracellular $\mathrm{pH}$ due to a decrease in extracellular $\mathrm{pH}$.

The food that goes into the stomach until it comes out of the stomach requires about 90 minutes of normal time, while the time used in this study was 180 and 360 minutes, or 4 times the minimum amount of time required to select BAL become probiotic bacteria. The aim is to ensure BAL really be able to survive in an acidic $\mathrm{pH}$.

\subsection{Lactic Acid Bacteria Isolates resilience Bile Salts}

Lactic acid bacteria as probiotic candidate must be able to pass through the digestive tract trending conditions, in order to survive and grow. One is when bacteria enters the intestine where part or bile secreted in the gut.Journey probiotics in the digestive tract can face a variety of physiological conditions, therefore $\mathrm{BAL}$ as a candidate probiotic must be able to survive in various conditions of the upper digestive tract until reaching the intestine and can provide beneficial effects of probiotics on host (Babot et al. 2014). Resistance to bile salts is one of the most important selection criteria for probiotics because of the small intestine and the large intestine contains a high concentration of bile salts that are toxic to living cells (Floros et al., 2012). The concentration of bile salts in the duodenum and cecum chicken intestines are $0.008 \%$ and $0.175 \%$ (Lin et al., 2003).

Testing of lactic acid bacterial resistance to bile salts with a concentration of $0.3 \%$ and $0.5 \%$ for 5 hours, the result can be seen in Table 2 . 
Table 2. The mean percentage of lactic acidbacterial resistance to bile salts at concentrations of 0.3 and $0.5 \%$

\begin{tabular}{ccc}
\hline \multirow{2}{*}{ Isolates } & \multicolumn{2}{c}{ Viability } \\
\cline { 2 - 3 } & $\mathbf{0 . 3 \%}$ & $\mathbf{0 . 5 \%}$ \\
\hline F6 & $83,57 \mathrm{a}$ & $77,17 \mathrm{a}$ \\
C8 & $78,75 \mathrm{a}$ & $72,77 \mathrm{a}$ \\
C36 & $27,17 \mathrm{~cd}$ & $21,50 \mathrm{~b}$ \\
B2 & $22,86 \mathrm{~d}$ & $18,35 \mathrm{~b}$ \\
L15 & $24,65 \mathrm{~cd}$ & $23,57 \mathrm{~b}$ \\
I21 & $31,39 \mathrm{bc}$ & $21,96 \mathrm{~b}$ \\
P1 & $32,34 \mathrm{~b}$ & $25,80 \mathrm{~b}$ \\
\hline SE & $\mathbf{2 , 1 7 5}$ & $\mathbf{2 , 8 8 4}$ \\
\hline
\end{tabular}

Note: superscript $=$ different letters in the same column show highly significant $(\mathrm{P}<0.01)$

$\mathrm{SE}=$ Standard errer

The results showed that each isolate $\mathrm{LAB}$ have different survival were significantly $(\mathrm{P}<0.01)$ against 0.3 and $0.5 \%$ concentration of bile salts. These results showed all isolates of lactic acid bacteria can withstand the bile salts with a resistance of $>20 \%$ and berpotesi as probiotics. In accordance with theBezkorovainy statement (2001) criteria for probiotics have an estimated survival rate of at least $20-40 \%$ of the strains selected. Isolates F6 da C8 is an isolate which has the highest resistance to the concentration of bile salts (oxgall) $0.35 \%$ ie 83.57 and $78.75 \%$, namu peningktan already experienced a decrease in concentration of $0.5 \%$ bile salts (oxgall) to 77,17 and $72.77 \%$. Increasing the concentration of bile salts can cause a decrease in the number of lactic acid bacterial colonies greater (Farida, 2006). The higher the concentration of bile salts, then the number of Lactobacillus cells that die will increase (Ngatirah et al., 2000; Kusumawati 2000).

The results obtained in this study compares favorably with the results obtained by Lee et al. (2014) that the survival rates of isolates of P. pentosaceus F66 by $26.6 \%$ with $0.3 \%$ bile salt with 2-hour incubation.Results of this study was higher than the results Melia (2018) isolates of lactic acid bacteria were isolated from buffalo milk can withstand the bile salts with a concentration of $0.3 \%$ for 5 hours by $40.58 \%$ and remained at $0.5 \%$ concentration of $35.22 \%$.

Isolates $\mathrm{F} 6$ and $\mathrm{C} 8$ is also a difference isolates experienced a small decrease compared to isolates C36, B2, L15, I21 and P1.This small decline proves that isolates F6 and C8 have a great survival. As stated by Nurnaafi et al. (2015) which states that, in the great survival of lactic acid bacteria as probiotics are isolates which has a difference of a small decrease.
Lactic acid bacteria (LAB) were able to survive the conditions of bile salts caused by BAL enzyme bile salt hydrolases (BSH) which metabolize bile salts (Guo et al., 2010). BSH hydrolyze conjugated bile salts into conjugated bile salts that are not toxic for cells. Conjugated bile salts is bactericidal against sensitive microorganisms bile salts, can dissolve the lipid membranes and cause cell death (Begley et al. 2006). According to De Smet et al. (1995), Lactobacillus have an enzyme that can hydrolyze bile salts (bile salt hydrolase). This enzyme is able to modify the physicalchemical abilities possessed by bile salts that are not toxic to BAL.

Lactic acid bacteria also produce the enzyme $\beta$ galactosidase (Farida, 2006). Cells that die due to increased activity of the enzyme $\beta$-galactosidase to bile salts, the enzyme $\beta$-galactosidase, the lactic acid bacteria used to produce lactic acid from lactose (Surono, 2004). Increased activity of this enzyme is the bacterium attempts to adapt to the extracellular conditions, so that the speed of molecular diffusion of nutrients also increased and restrict the cell to control metabolism. Increased permeability of these cells results in intracellular material, such as cytoplasm and ribosomes extracted and undergo cell lysis. Though the cytoplasm serves as the venue for the hanpir all enzymatic reactions of cellular metabolism. In the cytoplasm, cell uses chemical energy to build and maintain cell structure and perform movements. Ribosomes synthesize proteins function. If this intracellular material, the bacteria can not metabolize, so it can not grow and even die (Lehninger, 2004).

\subsection{Hidropobisitas power Lactic Acid Bacteria Isolates}

Hydrophobicity of lactic acid bacteria can be seen in Table 3.

Table 3. Mean Hidropobisitas stickiness or lactic acid bacteria (\%)

\begin{tabular}{cc}
\hline Isolate & Hidropobisitas \\
\hline F6 & $92,67^{\mathrm{a}}$ \\
C8 & $92,23^{\mathrm{a}}$ \\
C36 & $89,72^{\mathrm{a}}$ \\
B2 & $81,05^{\mathrm{c}}$ \\
L15 & $89,29^{\mathrm{ab}}$ \\
I21 & $86,42^{\mathrm{b}}$ \\
P1 & $91,07^{\mathrm{a}}$ \\
\hline SE & $\mathbf{1 , 1 5 4}$ \\
\hline
\end{tabular}

Note: superscript $=$ different letters in the same column show highly significant $(\mathrm{P}<0.01)$

$\mathrm{SE}=$ Standard errer 
Results of analysis of variance showed that each isolate different viability sanagat BAL had significantly $(\mathrm{P}<0.01)$. The average of the highest viability of 89.72 to $92.67 \%$, ie isolates $\mathrm{C} 36, \mathrm{P} 1, \mathrm{C} 8$ and $\mathrm{F} 6$. These results indicate that each isolate has a high viability so that it can be used as a probiotic candidates. Because of the presence of BAL BAL attached to it is able to survive longer in the digestive tract that can further proliferate. Lactic acid bacteria are not able to stick with the good will come together intestinal peristalsis wasted leftovers for the next with feces. The next implication BAL were able to stick in the gut would be able to give the effect of intestinal defenses better to reject the possibility of pathogenic bacteria that are capable of adhering to the intestine.

\subsection{Lactic Acid Bacteria Isolates Resilience Against Bacterial Pathogens}

Criteria of lactic acid bacteria (LAB) used as a probiotic culture of which is its ability to inhibit pathogenic bacteria so that they can compete with pathogenic bacteria to maintain a balance of normal intestinal microflora (Salminen et al., 2004).

Diameter of clear zone formed as BAL antagonistic activity against pathogenic bacteria (Escherichia coli, Staphylococcus aureus and Salmonella enteritidis) can be seen in Table 4.

Table 4. The mean diameter of inhibition zone of lactic acid bacteria against pathogens

\begin{tabular}{cccc}
\hline \multirow{2}{*}{ Isolate } & \multicolumn{3}{c}{ Inhibition zone diameter (mm) } \\
\cline { 2 - 4 } & $\begin{array}{c}\text { Escherichia } \\
\text { coli }\end{array}$ & $\begin{array}{c}\text { Staphylococc } \\
\text { us aureus }\end{array}$ & $\begin{array}{c}\text { Salmonella } \\
\text { enteritidis }\end{array}$ \\
\hline F6 & $10,49^{\mathrm{b}}$ & $14,05^{\mathrm{a}}$ & $18,08^{\mathrm{a}}$ \\
C8 & $8,89^{\mathrm{c}}$ & $13,70^{\mathrm{ab}}$ & $14,18^{\mathrm{b}}$ \\
C36 & $7,33^{\mathrm{d}}$ & $13,19^{\mathrm{ab}}$ & $12,10^{\mathrm{b}}$ \\
B2 & $10,59^{\mathrm{b}}$ & $11,11^{\mathrm{d}}$ & $14,46^{\mathrm{b}}$ \\
L15 & $10,92^{\mathrm{b}}$ & $11,28^{\mathrm{cd}}$ & $12,22^{\mathrm{b}}$ \\
I21 & $12,01^{\mathrm{a}}$ & $12,31^{\mathrm{bcd}}$ & $12,02^{\mathrm{b}}$ \\
P1 & $11,86^{\mathrm{a}}$ & $13,01^{\mathrm{bc}}$ & $12,87^{\mathrm{b}}$ \\
\hline SE & $\mathbf{. 3 0 9}$ & $\mathbf{0 . 5 4 7}$ & $\mathbf{0 . 7 9 7}$ \\
\hline
\end{tabular}

Note: superscript $=$ different letters in the same column show highly significant $(\mathrm{P}<0.01)$

$\mathrm{SE}=$ Standard errer

The results of the study Table 4 shows the inhibition of lactic acid bacteria isolates against bacterial pathogens (Echerichia coli, Staphylococcus aureus and Salmonella enteritidis) highly significant $(\mathrm{P}<0.01)$. Isolates that have inhibitory Echerichia coli bacteria highest are I21 and P1 isolates with inhibition zone diameter of 12.01 and 11.86 $\mathrm{mm}$. Average - Average Echerichia coli bacteria inhibition of each isolates in this study is 7.33 to $12.01 \mathrm{~mm}$. These results are higher than the results obtained by Awalia (2017) the ability of lactic acid bacteria isolated from the gastrointestinal tract of chicken bangkok to inhibitionEscherichia coli8.6 mm. The research Halim and Zubaidah (2013) the ability of lactic acid bacteria isolated from mustard sauce to the inhibition of Escherichia coli is $10.73 \mathrm{~mm}$. Diameter inhibitory Lactobacillus plantarum to the bacterium Escherichia coli by $13.75 \mathrm{~mm}$ (Sunaryanto and Marwoto, 2012).

The diameter of inhibition zone of lactic acid bacteria isolates of Staphylococcus aureus against which the highest is $14.05 \mathrm{~mm}$ F6 isolates (Table 4). Visible diameter clear zone around the well, and showed antimicrobial activity generated by each of the lactic acid bacteria. Inhibition results in this study is higher than Awalia research (2017) with a diameter of $8.3 \mathrm{~mm}$ inhibition zone. The results ofresearch Halim and Zubaidah (2013), the ability to isolate lactic acid bacteria isolated from mustard sauce to the inhibition of Staphylococcus aureus was $10.68 \mathrm{~mm}$.

Isoalat inhibition zone diameter of lactic acid bacteria against Salmonella enteritidis isolates highest are F6 ie 18:08 $\mathrm{mm}$ (Table 4). These results are higher than the results Chotiah and Damayanti (2018), in which the inhibition of bacteria Bifidobacterium Dentium against Salmonella enteritidis bacteria by $10 \mathrm{~mm}$.

One mechanism in menghabat LAB isolates of pathogenic bacteria is an organic acid. Organic acids, in particular acetic acid and lactic acid has a strong inhibitory effect against Gram-negative bacteria and as a major antimicrobial compounds responsible for the inhibitory activity of probiotics against pathogens (Makras et al., 2006). Surono (2004) explains, the antimicrobial effect is the result of a decrease in $\mathrm{pH}$ and organic acids form undissociated. Undissociated acid can penetrate the cell wall of Gramnegative bacteria that have a high lipid content, ie $11-22 \%$. Extracellular acidic conditions resulted in the pores of the cell wall of Gram-negative bacteria occur enlarged and cell permeability, so that many intracellular material out. Low extracellular $\mathrm{pH}$ conditions lead to acidification of the cell cytoplasm and acid that does not dissociate into lipophilic so that it can diffuse into the membrane. This situation would disrupt the transport system of the substrate in the cell, so that there is no supply of nutrients for cell metabolism processes. 
Antimicrobial compounds produced by LAB in addition to the organic acid is a bacteriocins. The main target of bacteriocins produced is the cytoplasmic membrane, as bacteriocins initiate reactions that alter the permeability of the membrane that disrupts the transport of membrane or eliminate the kinetic energy of the protons that produce inhibition of energy production and biosynthesis of proteins or nucleic acids (Nissen-Meyer et al., 1992).

Gram negative bacteria are more sensitive to antimicrobial metabolites compared with Gram-positive bacteria. The lactic acid produced can weaken the permeability of Gram-negative bacteria by damaging the outer membrane of Gram-negative bacteria. Gram-negative bacteria do not have a proton pump mechanism which is able to balance the $\mathrm{pH}$ in cells and other antimicrobial substrate can not penetrate the cytoplasmic membrane (Cotter and Hill, 2003). The damage that occurs in the outer membrane of bacteria, occurs due to Gram-negative bacteria such as E. coli and salmonella has a thin layer of the cell wall and a thick lipid reaches $11-22 \%$. Extracellular acidic state makes enlarged pores cells, increased cell permeability, so that the material is not required for entry into the cell metabolism, whereas many cell intracellular material coming out. Intracellular material such as cytoplasm and ribosomes can not perform its function to transport nutrients and synthesize proteins.

BAL resulting inhibition zone against bacterial pathogens third overall indicate that the antimicrobial compounds produced are able to inhibit the growth of pathogenic bacteria. Seventh lactic acid bacteria isolates had different inhibitory zone-beda terhadap bacterial pathogens, this is because each-masing isolates baktelactic acid ri mehave kCapacity of Different-beda in membunuh pathogenic bacteria.

\section{CONCLUSION}

In concluded the ability as a candidate probiotic mixture then isolate $\mathrm{F} 6$ from durian fermented and isolate $\mathrm{C} 8$ from buffalo milk fermented (Dadih) are able to live at $\mathrm{pH} 2.5$ for 3 hours of $92.75 \%$ and $86.06 \%$, at 6 hours of 72.44 and $71.42 \%$, the bile salt $0.3 \%$ were $83.57 \%$ and $78.75 \%$ and the concentration $0.5 \%$ are $77.17 \%$ and $72.77 \%$, with viability were $92.67 \%$ and $92.23 \%$, while the ability to kill pathogens such as Escherichia coli was 10.49 and $8.89 \mathrm{~mm}$, Staphylococcus aureus was 14.05 and $13.70 \mathrm{~mm}$, dan Salmonella enteritidis was 18.08 and $14.18 \mathrm{~mm}$.

\section{REFERENCES}

[1] Awalia, F. 2017. Isolation and test the antibiotic activity of lactic acid bacteria in the intestine bangkok chicken gallus domesticus. Thesis. Faculty of Medicine and Health Sciences. Makasar.Makasar Alauddin State Islamic University.

[2] Babot J.D., E. Arganaz-Martinez, L.Saavedra, M.C. Apella, A.P.Chaia. 2014. Selection of indigenous lactic acid bacteria to reinforce the intestinal microbiota of newly hatched chicken - relevance of in vitro and ex vivo methods for strains characterization. Res Vet Sci. 97: 817.doi: 10.1016 / j.rvsc.2014.06.001.

[3] Begley, M., C.Hill, C.G.M.Gahan. 2006. Bile salt hydrolase activity in probiotics. Appl Environ Microbiol.73 (3): 17291738.doi: 10.1128 / AEM.72.3.17291738.

[4] Bezkorovainy, A. 2001. probiotics: determinants of survival and growth in the gut.Us National Library of Medicime National Institutes of Health. 73: 399-405.

[5] Cahyono, B. 2004.How to Improve Cultivation of Broiler.YayasanPustaka Nusantara, Yogyakarta.

[6] Castañon, J.I.R. 2007. History of the use of antibiotics as growth promoters in European poultry feeds. Poult Sci. 86: 2466-2471.

[7] Cotter, P.D., and C. Hill. 2003. Surviving the acid test: responses of gram-positive bacteria to low pH.MicrobiolMolBiol Rev 67 (3): 429453.doi: 10.1128 / MMBR.67.3.429-453.2003

[8] [FAO and WHO] Food and Agriculture Organization of the United Nations and the World Health Organization. 2002. Guidelines for evalution of probiotics in food. Report of the Joint FAO / WHO Working Group on drafting guidelines for the evaluation of probiotics in food. London Ontario $(\mathrm{CN})$ : FAO / WHO.

[9] [FAO / WHO] Food and Agriculture Organization / World Health Organization. 2006. probiotics in food: Health and nutritional properties and guidelines for evaluation. Rome: FAO / WHO.

[10] Fardiaz, S. 1989. Food Microbiology.Inter-University Center for Food and Nutrition.Bogor Agricultural Institute.

[11] Farida, E. 2006. Selection testing candidate probiotic lactic acid bacteria isolates the results of the local and its ability to inhibit the secretion of interleukin-8 from the flow cell 116 . Thesis HCT.Postgraduate.Bogor Agricultural Institute.

[12] Floros, G., M. Hatzikamari, E. Lipoupou-Tzanetaki, and N. Tzanetakis. 2012. Probiotic and technological properties of facultatively heterofermentative Lactobacili from greek traditional cheeses. Food Biotechnology. 26 (1): 85-105.

[13] Fuller R. 1992.probiotics: The Scientific Basis. London (GB): Chapman \& Hall.

[14] Fuller R. 1989.Probiotics in man and animals.Journal of Applied Bacteriology. 66, 365-378.

[15] Hardiningsih, R., and T. Yulinery Napitupulu RNR. 2006. Isolation and test the resistance of some isolates of lactobacilli at low pH. Biodiversity. 7 (1): 15-17. 
[16] [Ministry of Agriculture] Ministry of Agriculture. 2009. Regulation of the Minister of Agriculture of the Republic of Indonesia Number 18 of 2009 on Livestock and Animal Health. Jakarta (ID): Ministry of Agriculture.

[17] Kusmiati and A. Malik. 2002. Activities bacteriocin from Leuconostoc mesenteroides bacteria pbac1 on various media. Makara, Health. 6 (1): 1-6.

[18] Kusumawati, N. 2002.Selection indigenus lactic acid bacteria as probiotics genus with the ability to maintain balance and reduce faecal microflora in rat blood serum cholesterol [thesis]. Bogor: Post Graduate Program, Bogor Agricultural University.

[19] Leeson, S. and JD Summer. 1996. Commercial Poultry Nutrition. 2nd Ed. University Books.University of Guelph. Guelph, Ontario, Canada.

[20] Lehninger, A.L. 2004.Fundamentals of Biochemistry.Volume 1. Translation: MaggyThenawidjaja. Erland, Jakarta.

[21] Lin, J., O. Sahin, L. O. Michel and Q. Zhang. 2003. Critical role of the multidrug efflux pump cmeabc in bile resistance and in vivo colonisation of campylobacter jejuni. Infection and Immunity. 71 (8): 4250-4259.

[22] Maslami, V. 2019. Isolation and seleksi origin lactic acid bacteriapwishful fermentation West Sumatra and a glutamic acid enghasilplikasinya in mningkatkan performans and carcass quality. disertasi. FacultyAgriculture. Andalas University.

[23] Melia, S. 2018. The potential of lactic acid bacteria isolates from buffalo milk as probiotics and bacteriocins producer for functional food. Dissertation. Faculty of Animal Husbandry. Andalas University.

[24] Ngatirah, E.,E.S.Harmayanti, and T. U. Rahayu. 2000. Selection of lactic acid bacteria as probiotic agents that have the potential to lower cholesterol. Proceedings of the National Seminar on Food Industry.

[25] Nurnaafi, A.I., Setyaningsih and Desniar. 2015. Potential probiotic lactic acid bacteria bekasam origin tilapia. Journal of Food Technology and Industry. 26 (1): 109-114.

[26] Russell, JB, 1992, Another Explanation for The Toxicitry of Fermentation Acid at Low $\mathrm{pH}$ : Anion Accumulation versus uncoupling, J. Appl. Bacterial 73: 363-370.

[27] Salminen, S., A.V. Wright, and A. Ouwehand. 2004. Lactic Acid Bacteria: Microbiology and Functional Aspects. 3rd edition. Revised and Expanded. New York: Marcel Dekker, Inc.

[28] Siegumfeldt, H., K.B. Rechinger, And M. Jakobsen. 2000. Dynamic changes of $\mathrm{pH}$ in individual intracelluler lactic acid bacterium cells in response to a rapid drop in extracellular $\mathrm{pH}$. Appl. Environ. Microbiol. 66: 2330-2335

[29] Sieladie, D.V., N.F. Zambou, P.M. Kaktcham, A. and F. Cresci Fonteh. 2011. Probiotic properties of Lactobacillus strains isolated from raw cow milk in the western highlands of cameroon. Innovative Romanian Food Biotechnology. 9: 1228.
[30] Simadibrata, M. 2010. Probiotics-Role in the World Medical.University of Indonesia. Jakarta.

[31] Surono, IS. 2004. Probiotics - Fermented Milk and Health. Jakarat (ID): Tri CiptaKarya.

[32] Tokatli, M., G. Gulgor, SB Elmaci, NA Isleyen and F. Ozcelik. 2015. In vitro properties of indegenenous of potential probiotic lactic acid bacteria. Biomed Reseach International: 1-8.

[33] Tao Y, Yu G, Chen D, Pan Y, Liu Z, Wei H, Peng D, Huang L, Wang Y, Yuan Z., 2012. Determination of 17 macrolide antibiotics and avermectins residues in meat with accelerated solvent extraction by liquid chromatography- tandem-mass spectrometry. J Chrom B. 897: 64-71. doi: 10.1016 / j.jchromb.2012.04.011.

[34] Timmerman, HM, CJ Koning, L. Murder, FM Rombouts, and AC Beymen. 2004. Monostrain, Multistrain and Multispecies probiotics: A Comparison of Functionality and Efficacy. Intr. Jour. Food Microbiol. 96: 219-233.

[35] Timmerman, HM, A. Veldman, E. van den Elsen, FM Rombouts and AC Beymen. 2006. Mortality and Growth Performance of Broiler Given Drinking Water supplemented with Chicken - Specific probiotics. J. Poult. Sci. 85: 13831388.

[36] Tokatli, M., G. Gulgor, SB Elmaci, NA Isleyen and F. Ozcelik. 2015. In vitro properties of indegenenous of potential probiotic lactic acid bacteria. Biomed Reseach International: $1-8$.

[37] Van de Guchte M, Serror P, Chervaux C, Smokvina T, Emrlich SD, Marguin M. 2002. Stress responses in lactic acid bacteria. Antonie van Leeuwenhoek 82: 187-216.

[38] Vignaroli, C.,S. Pasquaroli, G. Zandri, L.F. Aquilanti. 2011. MultidrugresistantBiavasco enterococci in meat and animal faeces and co-transfer of resistance from an Enterococcus Durans to a human Enterococcus faecium.CurrMicrobiol. 62: 1438-1447.doi: 10.1007 / s00284-011-9880-x.

[39] Vinderola, C.G., And J.A. Reinheimer. 2003. Lactic acid starter and probiotic bacteria: a comperative "in vitro" study of the probiotic characteristics and biological barrier of resistance. Food Research International. 36: 859-904. 